\title{
DIVERSITY OF MICROBES IN SOIL AGGREGATE FRACTIONS UNDER DIFFERENT LAND-USES IN NORTHERN GUINEA SAVANNA, NIGERIA
}

\author{
${ }^{* 1}$ Lawal, H. M., ${ }^{1}$ Salifu, U. M., ${ }^{1}$ Amapu, I. Y., ${ }^{2}$ Atta, H. I. \\ ${ }^{1}$ Department of Soil Science, Faculty of Agriculture, Ahmadu Bello University, Zaria, Nigeria. \\ ${ }^{2}$ Department of Microbiology, Faculty of Life Sciences, Ahmadu Bello University, Zaria, Nigeria \\ *Corresponding author's e-mail: lawalhalima2@gmail.com
}

\begin{abstract}
Microorganisms play vital role in keeping soil healthy. Bacteria, Fungi and Actinobacteria are active in degrading soil organic matter which improves soil ecosystem functioning. There exists a dearth of information on the influence of land-use on diversity of microbes in different soil aggregate sizes in Northern Guinea Savanna of Nigeria. This study assessed the diversity of soil microbes under six different land-use practices namely forest, fallow, pasture legume, pasture cereal, date palm plantation and continuous cultivated. In each land-use soil samples were collected at two depths $(0-5 \mathrm{~cm}$ and $5-20 \mathrm{~cm})$. The soil samples were divided into two parts, one part was left as collected from the field sites (bulk soil) and the other part was separated into three aggregate fractions ( $>250 \mu \mathrm{m},>53 \mu \mathrm{m}$ and $<53 \mu \mathrm{m}$ ). Bacteria, Fungi and Actinobacteria were cultured, isolated and identified, and some soil chemical properties were determined. Colony forming units per gram of soil (CFU/g soil) was computed for the soil microbes. Results revealed that Bacteria is the predominant soil microbe followed by Actinobacteria and then Fungi in all the land-uses. Bacteria population ranged from $1.49 \times 10^{7}$ to $8.65 \times 10^{7} \mathrm{CFU} / \mathrm{g}$ soil, Actinobacteria population ranged from $9.32 \times 10^{5}$ to $5.85 \times 10^{6} \mathrm{CFU} / \mathrm{g}$ soil and Fungi population ranged between $6.75 \times 10^{4}$ and $4.21 \times 10^{5} \mathrm{CFU} / \mathrm{g}$ soil. Higher microbial population were observed in forest soil than soils of the other land-uses. Continuously cultivated land had the least microbial population. Silt + clay soil fraction had significantly higher bacteria while the bulk soil was significantly richer in fungal population.
\end{abstract}

Keywords: Soil microbes, population, diversity, aggregate fractions and land use.

\section{INTRODUCTION}

The continued existence of human beings is predicated upon the quality of land resources available for use. Land is put into both agricultural and non-agricultural uses by man which tend to affect the quality of the soil and the environment (FAO, 2010; Eneje and Eke, 2012). Land-use determines the content soil of organic matter through plant litter production which constitute the major source of organic matter in soil (Pulleman et al., 1999). Organic matter mediates several vital processes in soil and determines to a great extent the kind of microorganisms found in soils (Borie et al., 2008; Joshi et al., 2009). Soil serves as the natural habitat for microorganisms and their function is coordinated primarily by the kinds of food materials available to them in soil. Soil microbes play active roles in degrading these food materials (organic matter) which helps in improving the proper functioning of the soil ecosystem. Hence, land-use practices with high litter production or deposits would boost the activities of soil microbes and would have greater potential and capacity for agriculture (food crop production). Many anthropogenic activities in soil poses threat to agriculture, human health, environment and soil fertility status, hence, may consequently have impact on soil microbial population and diversity. Nidhi et al. (2019) reported significant loss in biodiversity when natural environments were modified or converted to other uses, especially for continuous and intensive cultivation. There is scarcity of information on microbial population and diversity in varying soil aggregates sizes under different land-uses in the Northern Guinea Savanna of Nigeria. The objective of this study is to determine the effect of land-use on the colony forming units and diversity of soil bacteria, fungi and actinobacteria, and to assess the distribution and diversity of these soil microbes in soil aggregate fractions. 


\section{MATERIALS AND METHODS}

\section{Study Sites}

The study sites were six locations under different land-uses in the Northern Guinea Savanna of Nigeria as shown in the Table below.

\begin{tabular}{|c|c|c|}
\hline \multicolumn{2}{|r|}{ Land-use } & Site information and history \\
\hline 1. & Forest & $\begin{array}{l}30 \text { years Tamarindus indica plantation covering about } 0.32 \text { ha in Afaka forest } \\
\text { reserve of Kaduna (Latitude } 10^{\circ} 34^{\prime} 5.1 \text { " to } 10^{\circ} 34^{\prime} 5.4^{\prime \prime} \mathrm{N} \text {, longitude } \\
7^{\circ} 20^{\prime} 22.1 \text { " to } 7^{\circ} 20^{\prime} 23.1^{\prime \prime} \text { E and altitude } 610 \mathrm{~m} \text { above sea level). }\end{array}$ \\
\hline 2. & Pasture legume & $\begin{array}{l}20 \text { years Gliricidia sepium plantation covering about } 0.15 \text { ha in National } \\
\text { Animal Production and Research Institute (NAPRI), Zaria (Latitude } \\
11^{\circ} 12^{\prime} 13.9^{\prime \prime} \text { to } 11^{\circ} 12^{\prime} 30.4^{\prime \prime} \mathrm{N} \text { longitude } 7^{\circ} 33^{\prime} 48.1^{\prime \prime} \text { to } 7^{\circ} 34^{\prime} 04.1^{\prime \prime} \mathrm{E} \text { and } \\
\text { altitude } 676 \mathrm{~m} \text { above sea level). }\end{array}$ \\
\hline 3. & Pasture cereal & $\begin{array}{l}46 \text { years Digitaria smutsii plantation covering about } 0.22 \text { ha in NAPRI, } \\
\text { Zaria, (Latitude } 11^{\circ} 12^{\prime} 11.5^{\prime \prime} \text { to } 11^{\circ} 12^{\prime} 12.9^{\prime \prime} \mathrm{N} \text {, longitude } 7^{\circ} 33^{\prime} 48.2^{\prime \prime} \text { to } \\
7^{\circ} 33^{\prime} 50.8^{\prime \prime} \text { E and altitude } 680 \mathrm{~m} \text { above sea level), }\end{array}$ \\
\hline 4. & Continuous cultivation & $\begin{array}{l}20 \text { years continuously cultivated maize field covering about } 0.20 \text { ha in } \\
\text { Institute for Agricultural Research farm, Zaria (Latitude } 11^{\circ} 10^{\prime} 31.9^{\prime \prime} \text { to } \\
11^{\circ} 10^{\prime} 32.2^{\prime \prime} \mathrm{N} \text {, Longitude } 7^{\circ} 36^{\prime} 34.1^{\prime \prime} \text { to } 7^{\circ} 366^{\prime} 34.5^{\prime} \mathrm{E} \text { and altitude } 702 \mathrm{~m} \\
\text { above sea level). }\end{array}$ \\
\hline 5. & Date palm plantation & $\begin{array}{l}20 \text { years date palm plantation in Ahmadu Bello University, Samaru, Zaria } \\
\text { (Latitude } 11^{\circ} 09^{\prime} 38.2^{\prime \prime} \text { to } 11^{\circ} 09^{\prime} 47.8^{\prime \prime} \mathrm{N} \text {, longitude } 7^{\circ} 37^{\prime} 59^{\prime \prime} \text { to } 7^{\circ} 38^{\prime} 32.0^{\prime} \mathrm{E} \\
\text { and altitude } 675 \mathrm{~m} \text { above sea level). }\end{array}$ \\
\hline 6. & Fallow land & $\begin{array}{l}30 \text { years fallow field dominated by Tridax, Elephant grass, Spear grass and } \\
\text { Shrubs in Institute for Agricultural Research field, Zaria (Latitude } 11^{\circ} 10.476 \text { ' } \\
\text { to } 11^{\circ} 10.480^{\prime} \mathrm{N} \text { longitude } 7^{\circ} 36.790^{\prime} \text { to } 7^{\circ} 36.816 \mathrm{E} \text { and altitude } 678 \mathrm{~m} \text { above } \\
\text { sea level). }\end{array}$ \\
\hline
\end{tabular}

These six different land use practices listed above served as the treatment for this study. The average minimum and maximum annual temperature of the Northern Guinea Savanna of Nigeria is $21.1^{\circ} \mathrm{C}$ and $35.5^{\circ} \mathrm{C}$ respectively, with long-term mean annual rainfall of $1270 \mathrm{~mm}$ in Afaka and $1011 \pm 161 \mathrm{~mm}$ in Samaru.

\section{Soil Sampling and Preparation}

A simple random sampling technique was adopted to collect soil samples. The field was divided into three (3) parts to form replications, where no replication exists. Soils were collected with the aid of a clean auger, at two depths $(0-5 \mathrm{~cm}$ and $5-20 \mathrm{~cm})$ at field moist state. In each replication, soils were collected from 20 points and bulked as composite soil sample. These soil samples were immediately stored in airtight containers with ice pack and later kept in a refrigerator at $4^{\circ} \mathrm{C}$. Each of the soil samples were later separated to three portions, one portion was kept in the refrigerator as collected from the field (bulk soil). The second portion was separated by wet sieving using distilled water and sterilized nest of sieves $(250 \mu \mathrm{m}$ and $53 \mu \mathrm{m})$, into small macro-aggregates $(>250 \mu \mathrm{m})$, micro-aggregates $(>53 \mu \mathrm{m})$ and silt plus clay $(<53 \mu \mathrm{m})$ fractions then refrigerated. The last portion of the soil composite samples were air-dried and sieved through $2 \mathrm{~mm}$ sieve for soil chemical analyses.

\section{Soil Analysis}

The $2 \mathrm{~mm}$ sieved air-dried soil sample was used for the determination of soil organic carbon (Nelson and Sommers, 1982), Soil pH (Mcleans, 1982), Total nitrogen (Bremner and Mulvaney, 1982) Available P by Bray No. 1 acid fluoride method, exchangeable bases (Rhodes, 1982), Effective cation exchange capacity and exchange acidity. The bulk soil and aggregate fractions were used for the determination of bacteria, fungi and actinomycetes population and diversity following the conventional procedures as described by Xu et al (2014), and Anasuya et al (2016).

\section{Enumeration and Isolation of Microorganisms from Soil Samples}

A suspension of each soil sample was prepared by weighing one gram of soil sample into nine milliliters of sterile distilled water; and a tenfold dilution was prepared up to dilution $10^{-5}$. Aliquots of $0.1 \mathrm{~mL}$ was obtained from dilution $10^{-5}$ and inoculated (by spread plate method) on the surface of freshly prepared nutrient agar for the enumeration of bacteria; while the same volume from dilution $10^{-4}$ was inoculated onto the surface of freshly prepared oat meal agar and saboraud dextrose agar for the enumeration of actinobacteria and fungi, respectively. The inoculated plates were incubated at room temperature for a period of $3-7$ days with the exception of the plates for bacterial isolation which were incubated at $37^{\circ} \mathrm{C}$ for 24 hours.

After the period of incubation, the colonies observed were counted using a colony counter (Stuart SC6/1-model) and expressed as colony forming units per gram of soil (CFU/g soil). Plates having more than 300 colonies were described as too numerous to count. The colonies were aseptically transferred based on the different morphology into the following freshly prepared culture media, 
nutrient agar slants (bacteria), saboraud dextrose agar slants (fungi) and oat meal agar slants (Actinobacteria). The pure isolates obtained for incubated as previously described above and subjected to further identification.

\section{Identification}

Bacteria and actinobacteria isolates were identified through various biochemical tests carried out while the fungal isolates were identified by microscopy and the use of an ATLAS.

Statistical Analysis

Data obtained in this study were subjected to statistical analysis using the general linear model (GLM) procedure of SAS 9.2 package. Differences among treatment means was separated by Duncan multiple range test (DMRT)

\section{RESULTS}

\section{Soil Fertility Indicators}

Variation in land-use conferred significant differences in soil properties of the study areas (Table1). Soil reaction at $0-5 \mathrm{~cm}$ soil sampling depth, range from moderately acidic in continuous cultivated, date palm, pasture cereal and pasture legume to slightly acidic in fallow and forest soils. However, at subsurface soils $(5-20 \mathrm{~cm})$ the soil $\mathrm{pH}$ ranges from strongly acidic to moderately acidic and slightly acidic in date palm and forest soil. Soil organic carbon (SOC) content was generally low, except in forest soil and pasture field where organic carbon (OC) content was moderate. Total nitrogen and Available P contents are moderate across all evaluated land-use but high in forest soil. However, effective cation exchange capacity (ECEC) range from low to moderate except at $0-5 \mathrm{~cm}$ depth of the forest soil where the ECEC was high.

\section{Soil Microbial Count}

The influence of land-use and soil aggregate fractions on soil microbial population and diversity at $0-5 \mathrm{~cm}$ and $5-20 \mathrm{~cm}$ soil sampling depths is presented on Table 2. Variation due to land-use revealed mean values of microbial counts was significant for aacteria and fungi but not significant for the actinobacteria.

Forest soil had significantly higher bacterial population and diversity than all other land-uses at both soil depth, except in soils of fallow, pasture cereal and pasture legume land-uses at $0-5 \mathrm{~cm}$ sampling depth, which had statistically similar bacterial population as the forest soil. However, the least bacterial population were observed in soils of continuous cultivated land-use.

Forest soil also had significantly higher fungal colony forming units than all other evaluated land-use at both $0-5$ and 5-20 cm soil depths except at 0-5 cm sampling depth, where soils of pasture 
Table 1: Chemical properties of soil under different land-uses at 0-5 and 5-20 cm sampling depths

\begin{tabular}{|c|c|c|c|c|c|c|c|c|c|c|}
\hline \multicolumn{11}{|c|}{ Soil properties } \\
\hline Treatment & $\mathrm{pH} \mathrm{CaCl}_{2}$ & $\mathrm{OC}$ & $\mathrm{TN}$ & Avail. P & $\mathrm{Ca}$ & $\mathrm{Mg}$ & $\mathrm{K}$ & $\mathrm{Na}$ & E.A & ECEC \\
\hline & & \multicolumn{2}{|c|}{$\leftarrow \mathrm{g} \mathrm{Kg}^{-1} \rightarrow$} & $\mathrm{mg} \mathrm{Kg}^{-1}$ & & $\leftarrow$ & \multicolumn{2}{|c|}{$\mathrm{c} \mathrm{mol} \mathrm{Kg}{ }^{-1}$} & \multicolumn{2}{|r|}{$\rightarrow$} \\
\hline Land use & \multicolumn{10}{|c|}{0 - 5 cm sampling depth } \\
\hline Continuous cultivation & $5.90^{\mathrm{b}}$ & $3.11^{\mathrm{c}}$ & $1.4^{\mathrm{b}}$ & $8.86^{\mathrm{d}}$ & $1.60^{\mathrm{e}}$ & $0.41^{\mathrm{c}}$ & $0.20^{\mathrm{f}}$ & $0.52^{\mathrm{b}}$ & $0.41^{\mathrm{c}}$ & $3.14^{\mathrm{e}}$ \\
\hline Date palm & $5.85^{\mathrm{b}}$ & $5.88^{\mathrm{b}}$ & $2.2^{\mathrm{b}}$ & $16.53^{\mathrm{c}}$ & $3.07^{\mathrm{c}}$ & $0.51^{\mathrm{b}}$ & $0.44^{\mathrm{d}}$ & $0.29^{c}$ & $0.60^{\mathrm{b}}$ & $4.91^{\mathrm{c}}$ \\
\hline Fallow & $6.25^{\mathrm{a}}$ & $10.53^{\mathrm{a}}$ & $1.2^{\mathrm{b}}$ & $8.67^{\mathrm{d}}$ & $4.43^{\mathrm{b}}$ & $0.36^{\mathrm{d}}$ & $0.38^{\mathrm{e}}$ & $0.87^{\mathrm{a}}$ & $0.44^{\mathrm{c}}$ & $6.47^{\mathrm{b}}$ \\
\hline Forest & $6.18^{\mathrm{a}}$ & $12.47^{\mathrm{a}}$ & $3.6^{\mathrm{a}}$ & $18.84^{\mathrm{b}}$ & $10.73^{\mathrm{a}}$ & $1.31^{\mathrm{a}}$ & $0.89^{\mathrm{a}}$ & $0.52^{\mathrm{b}}$ & $0.20^{\mathrm{d}}$ & $13.64^{\mathrm{a}}$ \\
\hline Pasture cereal & $5.52^{\mathrm{d}}$ & $6.13^{\mathrm{b}}$ & $1.7^{\mathrm{b}}$ & $25.03^{\mathrm{a}}$ & $2.47^{\mathrm{d}}$ & $0.30^{\mathrm{e}}$ & $0.73^{\mathrm{b}}$ & $0.52^{\mathrm{b}}$ & $0.41^{\mathrm{c}}$ & $4.42^{\mathrm{d}}$ \\
\hline Pasture legume & $5.66^{\mathrm{c}}$ & $11.48^{\mathrm{a}}$ & $2.3^{\mathrm{b}}$ & $13.73^{\mathrm{c}}$ & $2.87^{\mathrm{c}}$ & $0.35^{\mathrm{d}}$ & $0.69^{c}$ & $0.30^{\mathrm{c}}$ & $0.77^{\mathrm{a}}$ & $4.98^{c}$ \\
\hline SE & 0.031 & 0.639 & 0.310 & 0.266 & 0.090 & 0.0084 & 0.011 & 0.014 & 0.014 & 0.089 \\
\hline Significant level & $* *$ & $* *$ & ** & $* *$ & $* *$ & $* *$ & $* *$ & $* *$ & $* *$ & $* *$ \\
\hline \multirow[t]{2}{*}{ C.V $(\%)$} & 0.90 & 13.61 & 24.32 & 2.82 & 3.74 & 2.69 & 3.41 & 4.99 & 5.12 & 2.46 \\
\hline & \multicolumn{10}{|c|}{5 - $20 \mathrm{~cm}$ sampling depth } \\
\hline Continuous cultivation & $5.64^{\mathrm{b}}$ & $3.64^{\mathrm{b}}$ & $1.30^{\mathrm{bc}}$ & $8.45^{\mathrm{e}}$ & $1.60^{\mathrm{e}}$ & $0.43^{\mathrm{b}}$ & $0.29^{\mathrm{e}}$ & $0.18^{\mathrm{c}}$ & $0.54^{\mathrm{bc}}$ & $3.04^{\mathrm{f}}$ \\
\hline Date palm & $6.25^{\mathrm{a}}$ & $5.18^{\mathrm{b}}$ & $1.20^{\mathrm{c}}$ & $10.71^{\mathrm{d}}$ & $2.93^{\mathrm{c}}$ & $0.42^{\mathrm{b}}$ & $0.51^{\mathrm{b}}$ & $0.70^{\mathrm{a}}$ & $0.50^{\mathrm{c}}$ & $5.06^{\mathrm{c}}$ \\
\hline Fallow & $5.46^{\mathrm{c}}$ & $5.55^{\mathrm{b}}$ & $1.03^{\mathrm{c}}$ & $6.39^{f}$ & $4.23^{\mathrm{b}}$ & $0.34^{\mathrm{c}}$ & $0.41^{\mathrm{c}}$ & $0.36^{\mathrm{b}}$ & $0.53^{\mathrm{bc}}$ & $5.88^{\mathrm{b}}$ \\
\hline Forest & $6.41^{\mathrm{a}}$ & $10.53^{\mathrm{a}}$ & $2.33^{\mathrm{a}}$ & $11.43^{\mathrm{b}}$ & $5.27^{\mathrm{a}}$ & $0.63^{\mathrm{a}}$ & $1.22^{\mathrm{a}}$ & $0.71^{\mathrm{a}}$ & $0.20^{\mathrm{d}}$ & $8.02^{\mathrm{a}}$ \\
\hline Pasture cereal & $5.47^{\mathrm{c}}$ & $11.49^{\mathrm{a}}$ & $1.20^{\mathrm{c}}$ & $11.08^{\mathrm{c}}$ & $2.20^{\mathrm{d}}$ & $0.27^{\mathrm{e}}$ & $0.48^{\mathrm{b}}$ & $0.70^{\mathrm{a}}$ & $0.58^{\mathrm{b}}$ & $4.22^{\mathrm{e}}$ \\
\hline Pasture legume & $5.41^{\mathrm{c}}$ & $9.17^{\mathrm{a}}$ & $1.53^{\mathrm{b}}$ & $12.77^{\mathrm{a}}$ & $2.77^{\mathrm{c}}$ & $0.31^{\mathrm{d}}$ & $0.33^{\mathrm{d}}$ & $0.58^{\mathrm{a}}$ & $0.70^{\mathrm{a}}$ & $4.68^{\mathrm{d}}$ \\
\hline SE & 0.051 & 0.775 & 0.093 & 0.099 & 0.08 & 0.0073 & 0.0102 & 0.042 & 0.022 & 0.0999 \\
\hline Significant level & $* *$ & $* *$ & $* *$ & $* *$ & $* *$ & $* *$ & $* *$ & $* *$ & $* *$ & $* *$ \\
\hline C.V $(\%)$ & 1.53 & 17.67 & 11.25 & 1.70 & 4.39 & 3.16 & 3.26 & 13.47 & 7.37 & 3.36 \\
\hline
\end{tabular}

( probability, $* *=$ Significant at $1 \%$ level of probability, NS = Not significant, SE $=$ Standard error, S.L $=$ Significance level, C.V = coefficient of variation, OC $=$ Organic carbon, $\mathrm{TN}=$ Total nitrogen, Avail. $\mathrm{P}=$ Available phosphorus, $\mathrm{Ca}=$ Exchangeable Calcium, $\mathrm{Mg}=$ Exchangeable Magnesium, $\mathrm{K}=\mathrm{Exchangeable}$ Potassium, Na $=$ Exchangeable Sodium, E.A $=$ Exchangeable acidity, ECEC $=$ Effective cation exchange capacity. 
Table 2: Heterotrophic Counts of microbes in soils of different land-use and aggregate fractions at 0 - $5 \mathrm{~cm}$ and $5-20 \mathrm{~cm}$ soil sampling depths

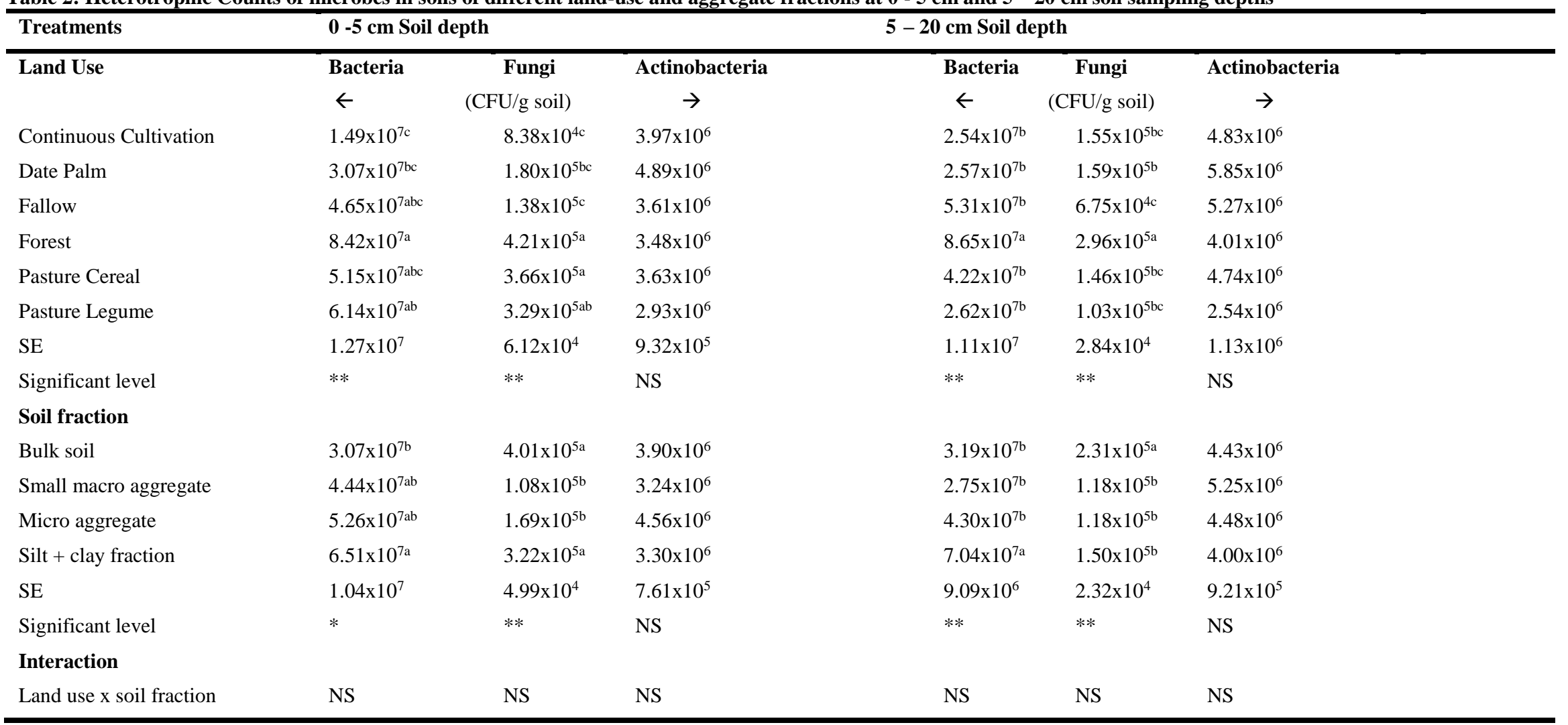

Means followed by the same letter (s) within the same column are not significant at $5 \%$ level of probability using Duncan Multiple Range Test (DMRT). $*=$ Significant at $5 \%$ level of probability, $* *=$ Significant at $1 \%$ level of probability, NS $=$ Not significant, $\mathrm{SE}=$ Standard error, C.V = coefficient of variation, CFU/g soil $=$ Colony forming units of microbes per gram of soil. 
Table 3: Predominant Microorganisms isolated from bulk soil and aggregates fractions of different land use systems

\begin{tabular}{|c|c|c|c|c|}
\hline \multirow[b]{2}{*}{ Land use } & \multirow[b]{2}{*}{ Soil Fraction } & \multicolumn{3}{|c|}{ Microorganisms Identified after Biochemical Tests at 0-20 cm soil depths } \\
\hline & & Bacteria & Actinobacteria & Fungi \\
\hline \multirow[t]{4}{*}{ Continuous Cultivation } & Bulk soil & Bacillus sp. & Actinomyces sp. & Phoma sp., \\
\hline & Small macroaggregate & Bacillus sp. & Actinomyces sp., Acanobacterium sp. & Microphomina sp., Sclerotium sp. \\
\hline & Microaggregate & Bacillus sp., Micrococcus sp. & $\begin{array}{l}\text { Acanobacterium sp.., } \\
\text { Micromonospora sp. }\end{array}$ & Aspergillus sp., Phoma sp. \\
\hline & Silt + clay & Micrococcus sp. & Streptomyces sp. & Trichoderma sp. \\
\hline \multirow{4}{*}{ Date Palm Plantation } & Bulk soil & Bacillus sp. & Actinomyces sp., Streptomyces sp. & Aspergillus sp., \\
\hline & Small macroaggregate & Bacillus sp. & Actinomyces sp. & Aspergillus sp., Sclerotium sp. \\
\hline & Microaggregate & Bacillus sp.., Micrococcus sp. & Actinomyces sp., Acanobacterium sp. & Verticillium sp. \\
\hline & Silt + clay & Bacillus sp. & Streptomyces sp., Actinomyces sp. & Sclerotium sp., Phoma sp. \\
\hline \multirow[t]{4}{*}{ Fallow } & Bulk soil & Bacillus sp. & Streptomyces sp. & Aspergillus sp., Phoma sp. \\
\hline & Small macroaggregate & Bacillus sp. & Streptomyces sp., Acanobacterium sp. & Trchoderma sp. \\
\hline & Microaggregate & Bacillus sp. & Actinomyces sp., Acanobacterium sp. & Aspergillus sp. \\
\hline & Silt + clay & Micrococcus sp., Bacillus sp. & Streptomyces sp. & Phoma sp., Aspergillus sp. \\
\hline \multirow[t]{4}{*}{ Forest } & Bulk soil & Bacillus sp. & Actinomyces sp., Streptomyces sp. & Aspergillus sp., Phoma sp. \\
\hline & Small macroaggregate & Bacillus sp. & $\begin{array}{l}\text { Acanobacterium sp., } \\
\text { Micromonospora sp. }\end{array}$ & $\begin{array}{l}\text { Phoma sp., Microphomina sp., } \\
\text { Penicillium sp., Sclerotium sp. }\end{array}$ \\
\hline & Microaggregate & Micrococcus, Bacillus & Actinomyces sp. & Phoma sp. \\
\hline & Silt + clay & Micrococcus, Bacillus & Actinomyces sp. & Aspergillus sp. \\
\hline \multirow[t]{4}{*}{ Pasture Cereal } & Bulk soil & Bacillus sp. & Acanobacterium sp. & Phoma sp. \\
\hline & Small macroaggregate & Bacillus sp., Micrococcus sp. & Acanobacterium sp. & Microphomina sp., Aspergillus sp. \\
\hline & Microaggregate & Bacillus sp. & Streptomyces sp. & Aspergillus sp., Penicillium sp. \\
\hline & Silt + clay & Micrococcus sp., Bacillus sp. & Actinomyces sp. & Sclerotium sp., Phoma sp. \\
\hline \multirow[t]{4}{*}{ Pasture Legume } & Bulk soil & Bacillus sp. & Acanobacterium sp. & Aspergillus sp. \\
\hline & Small macroaggregate & Bacillus sp. & Acanobacterium sp., Streptomyces sp. & Phoma sp., Penicillium sp. \\
\hline & Microaggregate & Micrococcus sp., Bacillus sp. & Actinomyces sp., Acanobacterium sp. & Aspergillus sp. \\
\hline & Silt + clay & Bacillus sp. & Acanobacterium sp. & Mucor sp., Sclerotium sp. \\
\hline
\end{tabular}


cereal and pasture legume land-uses had statistically similar fungal population as the forest soil. Soils of continuous cultivation land-use had the lowest fungal population and diversity at $0-5 \mathrm{~cm}$ soil depth while soil of date palm land-use was least in fungal population at $5-20 \mathrm{~cm}$ soil depth. Variation in the different land-use did not significantly influenced Actinobacteria population at both sampling depths.

Effect due to soil fraction, revealed Silt + clay fraction $(<53$ $\mu \mathrm{m})$ had significantly higher bacterial population than all other soil fractions at both $0-5$ and 5-20 cm depths, except at $0-5 \mathrm{~cm}$ sampling depth, where both the small macro-aggregate $(>250$ $\mu \mathrm{m})$ and micro-aggregate $(>53 \mu \mathrm{m})$ soil fractions had statistically similar bacterial population with the Silt + clay fraction.

Bulk soil had significantly higher fungal population than all other soil fractions at both sampling depths, except at $0-5 \mathrm{~cm}$ sampling depth where no significant difference was observed in fungal population between the bulk soil and Silt + clay fraction. However, actinobacteria population was not significantly influenced by soil fraction.

\section{Identification of Predominant Soil Microbes}

Table 3 shows the identity of the predominant bacteria, actinobacteria and fungal isolates in the soils of different landuses and aggregate sizes. Two bacterial genera identified to be predominant were Bacillus and Micrococcus. Bacillus spp were the most predominant (90\%) in all the land-use and soil fractions while Micrococcus $s p$ was common in only microaggregate and silt + clay fraction. Biochemical tests carried out, revealed four species of Bacillus were identified as: Bacillus subtilis, Bacillus mycoides, Bacillus megaterium and Bacillus polymyxa, which are very active in degrading organic matter in soil. Actinobacterial genera identified include; Actinomyces, Acanobacterium, Micromonospora and Streptomyces, while the fungal genera that are predominant in this study include Phoma, Microphomina, Aspergillus, Trichoderma, Verticillium, Sclerotium, Mucor and Penicillium.

\section{DISCUSSION}

The influence of land use and soil aggregate fraction on soil microbial population, diversity and activities revealed that the population and diversity of soil microbes were generally moderate in all the land uses. Although land uses with higher organic matter content such as forest, pasture legume, pasture cereal and date palm plantation had higher microbial activity which may be attributed to higher carbon storage in these soils. Leaf litter accumulation on forest floor, as well as detritus material during harvest in pasture and date palm land-uses are contributory to high carbon storage, nutrient cycling and consequently the fertility status in these soils. This is evident from the moderate to high ECEC obtained in these land-uses, which indicates less leaching of basic cations thus the slightly acidic soil reaction obtained in their underlying soils. The accumulation of plant litter in the less disturbed land-uses (forest, date palm, pasture cereal and legume) led to higher OC content in these land-uses and consequently higher bacteria communities because SOC is key factor to microbial diversity. Ausec et al. (2009) observed significant positive correlation between soil bacteria diversity and OC content in soil. Improved soil structure in the less disturbed land-uses (forest, date palm, pasture cereal and legume) promoted macro-porosity and pore continuity thereby reducing nutrient losses via leaching and consequently improves bacteria diversity.
The higher bacteria population and diversity in the forest soil than all other land-uses could be ascribed primarily to the high litter accumulation on forest floors and exudates released from tree roots which enhances availability of substrates for bacteria utilization. This high OM content might have caused increased in size, activity and diversity of microbial community thereby increasing nutrient cycling rate.

The relatively high counts of bacteria in these soils compared to those of fungi and actinobacteria could be attributed to the association of bacteria with particulate soil organic matter, particulate organic matter is the most readily available and abundant pool of carbon in soil albeit their short residence time. Since, bacteria are capable of utilizing more of simple organic substances than fungi and actinobacteria thus they have the ability to adapt to many different soil micro-environments (Hoorman and Islam, 2010), hence, their abundance in soil. Soil disturbance in continuous cultivated land-use due to tillage operation, and low OM content due to less vegetal cover, could lead to decrease in soil macro pores which may impair soil water drainage and gaseous exchange, and consequently, have adverse effect on soil bacteria and their abundance in continuous cultivated soil. However, bacteria are the smallest and most resilient microbes in soils (Hoorman and Islam, 2010) hence, can survive under harsh or changing soil conditions. This may be one of the reasons for the higher population of bacteria in the silt + clay fraction relative to the macroaggregate fraction. More so, bacteria have the capacity to utilize a wide variety of substrates and carry out wide array of processes thereby maintaining ecosystem stability and resilience.

Higher fungal population in the forest soil and soils of other undisturbed land-uses, as well as the bulk soil of the various land uses evaluated, signifies the ability of fungi to degrade tougher organic materials than bacteria (Aislabie and Deslippe, 2013). Furthermore, most soil fungi decompose recalcitrant organic residues high in cellulose and lignin. Fungi carbon use efficiency is about $40-55 \%$ so they store and recycle more C (10:1 C: $\mathrm{N}$ ratio) and less $\mathrm{N}$ in their cells than bacteria (Hoorman, 2011b). Fungi are more specialized but need a constant food source and grow better under no-till conditions. Therefore, their function is linked with good aggregation and soil carbon sequestration (Jean, 2005). More so, non-soil disturbance or non-tillage encourage macro aggregate formation, soil microbial biomass and increase fungal contribution to this biomass leading to increased soil aggregation and stabilization of organic matter (Six et al., 2006).

Lower fungal population in continuous cultivated soil relative to soils under the less disturbed land-uses may be ascribed to the fact that intensive cultivation disrupts fungal network and prevent their re-establishment. Alguacil (2008) observed poor soil health and fertility maintenance with impact on nutrient (phosphorus) and water uptake, and poor soil productivity due to significantly lower arbuscular mycorrhizal fungal diversity in tilled soil than in no till. In addition, application of nitrogen fertilizer in continuous cultivated soil affect the carbon to nitrogen ratio thereby increase the degradability of SOM consequently decrease in biomass over long periods which may ultimately lower microbial diversity. Also, reduced total porosity result in decreased oxygen content which may restrain 
the survival of fungal hence result in decreased soil fungal diversity.

The high abundance of fungi in macro aggregates and bulk soil may explain their roles in soil aggregate stability, as more macro aggregates means better soil structural stability thus higher fungal population. Association of fungi with chemically stable carbon fraction (Silva et al., 2011) which predominates the silt + clay fraction in addition to high SOM at $0-5 \mathrm{~cm}$ soil depth may have warranted high fungal counts in this soil fraction.

Actinobacteria exhibit their superior degradative abilities when highly complex organic materials such as lignin and hydrocarbons remain in the soil (Hoorman, 2011a; Hoorman and Islam, 2010; Asma et al., 2017). Actinobacteria are the greatest influencers of the recalcitrant carbon pool in soil. Their lower population and diversity observed in the continuous cultivated soil could be due to the low content of recalcitrant carbon as result of scanty soil cover and low nutrient status in this soil. However, the non-significant differences observed due to variation in land-use and soil fraction might be an indication that the recalcitrant organic matter in soils of evaluated land-use systems in this study, did not differ significantly or the recalcitrant carbon may be very low, hence may have little or no effect on the actinobacteria. In addition, the low soil $\mathrm{pH}$ (acidic) observed in these land-uses may not be favourable for the growth of antinobacteria since most of them thrive better in soils with high pH (Hoorman, 2011a).

\section{CONCLUSION}

Land-use practices have great influence on soil microbial activities; land-use systems with greater accumulation of organic matter usually have more food substrate and higher microbial population. This is evident from clearly profound changes observed in microbial communities due to differences in land-use and soil aggregate sizes. Land-use with less soil disturbances has better or more stable structure relative to the disturbed system and consequently, richer in microbial community. The smaller soil aggregate fractions were richer in bacteria possibly due to the resilient nature of bacteria while the bulk soil and macro aggregate were the richest in fungal communities. Land-use management that promotes soil organic matter buildup should be encouraged to establish and maintain good soil health, crop productivity and environmental wellbeing, since beneficial soil microbial communities enhance suppression of soil borne pathogens in agricultural soils.

\section{REFERENCES}

Aislabie, J. and Deslippe, J.R. (2013). Soil Microbes and their Contribution to Soil Services. In Dymond, J.R. (ed.) Ecosystem services in New Zealand conditions and trends. Pp 1-19.

Alguacil, M.M., Lumini, E. and Roldan, A. (2008). The impact of tillage practices on arbuscularmycorrhizal fungal diversity in subtropical crops. Ecol Appl 18:527-536

Anasuya, P., Sameer, K.S., Kumar, S.T., Yugal, K.M., Jayanta, K.P., Sethi, B.K. (2016). Isolation and Identification of Actinomycetes from Mangrove Soil and Extraction of
Secondary Metabolites for Antibacterial Activity. British Biotechnology Journal, 12 (2):1-3. ISSN: 2231-2927.

Asma, A.B., Shamsul, H., Rouf, A.B. (2017). Actinomycetes Benefaction Role in Soil and Plant Health. Microbial pathogenesis, 111: 458-467

Ausec, L., Kraigher, B. and Mandic-Mulec, I. (2009).

Differences in the activity and bacterial

community structure of drained grasslandand forest peat soils. Soil Biology and Biochemistry 41: 1874-1881, https://doi.org/10.1016/j.soilbio.2009.06.010

Borie, F., Rubio, R. and Morales, A. (2008). Arbuscular Mycorrhizal Fungi and Soil Aggregation. Journal of Soil Science and Plant Nutrition. 8 (2):9-18

Bremner, J.M. and Mulvaney, C.S. 1982. Nitrogen-total. In Page et al (eds) Methods of soil analysis. Part 2.

Eilers, K.G., Lauber, C.L., Knight, R., Fierer, N. (2010). Shifts in Bacterial Community Structure Associated with Inputs of Low Molecular Weight Carbon Compounds to soil. Soil Biology \& Biochemistry, 42: 896-903.

Elliot, E.T. (1986). Aggregate Structure and Carbon, Nitrogen, and Phosphorus in Native and Cultivated Soils. Soil Science Society American Journal. 50:627-633

Eneje, R.C., and Eke, C.N (2012). Effects of Land Use on Soil Carbon and Selected Structural Indices. Nigerian Journal of Soil and Environmental. Research. 10:101-108.

FAO. (2010). Data Sets on Land Use, Land Use Change, Agricultural and Forestry and their Applicability for National Green House Gas Report.

Fierer, N., Bradford, M.A., Jackson, R.B. (2007). Towards an ecological classification of soil bacteria. Ecology, 88:13541364.

Henry, D.F. (1990). Fundamentals of Soil Science. Textbook. Michigan State University.

Hoorman, J.J. (2011a). The Role of Soil Bacteria. Fact sheet Agriculture and Natural resources. The Ohio State University extension. SAG-13-11 Pp 1-4.

Hoorman, J.J. (2011b). The Role of Soil Fungus. Fact sheets Agriculture and Natural Resources, Ohio State University Extension. SAG-14-11. Pp 1-6.

Hoorman, J.J. and Islam, R. (2010). Understanding Soil Microbes and Nutrient Recycling. Fact Sheet Agriculture and Natural Resources. The Ohio State University Extension SAG16-10.

Jean, L.C. (2015). Importance of Microorganisms for Soil Aggregation. In book: Microorganisms in Soil: Role in Genesis and Functions, Pp 107-119. 
Joshi, S.R., Purabi, S., Khedarani, K. (2009). Characterization of Microbial Indicators to Assess the Health of Degraded Soil in Cherrapunjee, India-Highest Rainfall Area of the World. International Journal of Biotechnology and Biochemistry. 5(4):397-391

Lauber, C.L., Strickland, M.S., Bradford, M.A., Fierer, N. (2008). The Influence of Soil Properties on the Structure of Bacterial and Fungal Communities Across Land-use Types. 40: 2407-2415.

Mclean, E.O. (1982). Soil pH and lime requirement. In: Page, A.L. (ed.), Methods of Soil Analysis, Part II, 2nd ed., America Society of Agronomy Monograph No. 9. Madison, WI, pp. 199 224. Doi:10.2134/agronmonogr9.2.2ed.c12

Nelson, D.W. and L.E. Sommers (1982). Total Carbon, Organic Carbon and Organic Matter. In: AL. Page et al. (ed.). Methods of Soil Analysis, Part 2, $2^{\text {nd }}$ edition. Agronomy Monogram, 9:539-577.

Nidhi, S., Sarethy, I.P., Gupta, B., Gupta, S., Michael, K.D. (2019). Analyzing Functional Microbial Diversity: An Overview of Techniques-Microbial Diversity in the Genomic Era. Elsevier. Pp 79-102. ISBN:978-0-12-814849-5. https://doi.org/10.1016/B978-0-12-814849-5.00006-x.
Pulleman. M.M., Bouma, E.A., Van, E., Meijles, E.W. (1999). Soil Organic Matter Content as a Function of Different Land Use History. Soil Science Society of America Journal. 64 (2): 689-693.

Rhodes, J.D. (1982). Cation Exchange Capacity, In: Page, A.L and Miller R.H. (ed.). Method of Soil Analysis 2. Second edition. Agronomy Monogram. p. 149-157. ASA and SSSA, Madison, WI.

Silva, D.M., Luís, R.B., Elisângela F.R., Maria, H.P., Fungar Daniele, S., Eduardo, A. (2011). Identification of Fungi of the Genus Aspergillus Section Nigri Using Polyphasic Taxonomy. Brazilian Journal of Microbiology 42: 761-773ISSN 15178382.

Six, J., Frey, S.D. and Thiet, R.K. (2006). Bacterial and fungal contributions to carbon

sequestration in agroecosystems. Soil Science Society American Journal. 70:555-569.

Xu, D.B., Ye, W.W., Han, Y., Deng, Z.X., Hong, K. (2014). Natural Products from Mangrove actinomycetes. Mar drugs. 12 (15): 2590-2613. 